\title{
PENGARUH TERAPI AKTIVITAS KELOMPOK SOSIALISASI TERHADAP KEMAMPUAN BERSOSIALISASI PASIEN ISOLASI SOSIAL DIAGNOSA SKIZOFRENIA DI RUMAH SAKIT JIWA MENUR SURABAYA
}

\author{
Pandeirot M Nancye *, Luluk Maulidah** \\ Sekolah Tinggi Ilmu Kesehatan William Booth \\ Jln. Cimanuk 20 Surabaya
}

\begin{abstract}
ABSTRAK
Pendahuluan: Pasien dengan isolasi sosial cenderung suka menyendiri, tidak mau bergaul dengan orang lain, sehingga tidak mampu bersosialisasi. Masalah isolasi sosial dapat dilakukan terapi salah satunya yaitu TAKS. Tujuan dari penelitian ini adalah untuk mengetahui pengaruh terapi aktivitas kelompok sosialisasi pasien isolasi sosial diagnose skizofrenia di Ruang Puri Mitra Permata Harapan Rumah Sakit Jiwa Menur Surabaya. Metode: Penelitian ini menggunakan desain penelitian quasi eksperimen dengan metode one-group pra-post test design, populasi pada penelitian ini sebanyak 7 responden yaitu seluruh pasien skizofrenia yang mengalami masalah isolasi sosial dan jumlah sampel yang diambil yaitu 7 responden dengan menggunakan total sampling. Pengumpulan data menggunakan lembar observasi sebelum dan sesudah dilakukan TAK, kemudian di uji menggunakan uji wilcoxson. Hasil: Hasil dari penelitian ini semua responden tidak memiliki kemampuan bersosialisasi dengan baik sebelum dilakukan TAKS sebanyak 7 orang (100\%), sedangkan setelah dilakukan TAKS sebagian responden mampu untuk bersosialisasi dengan baik sebanyak 5 orang $(0,8 \%)$ dan ada pengaruh TAKS terhadap kemampuan bersosialisasi dengan nilai $p=0,025$. Diskusi: Faktor yang mendasari keberhasilan pelaksanaan TAKS salah satunya lama di rawat di RSJ, karena responden sering mendapatkan pengobatan dan perawatan seperti terapi aktivitas kelompok sosialisasi dan diharapkan terapi ini untuk terus dilakukan pada pasien, sehingga pasien dapat memiliki kemampuan bersosialisasi dengan baik.
\end{abstract}

Kata kunci : Terapi Aktivitas Kelompok Sosialisasi, Isolasi sosial. 


\section{PENDAHULUAN}

Skizofrenia merupakan gangguan jiwa yang banyak terdapat dalam masyarakat, dan sering dikonotasikan dengan keadaan gila (Ayub.2011). Ada beberapa tipe pada skizofrenia yaitu tipe paranoid, hebeperenik, dan katatonik. Salah satu masalah keperawatan pada skizofrenia yaitu isolasi sosial. Isolasi sosial merupakan keadaan dimana seorang individu mengalami gangguan penurunuan atau bahkan sama sekali tidak mampu berinteraksi dengan orang lain disekitarnya (Damaiyanti. 2008). Pada masalah isolasi sosial seseorang tersebut akan merasa kesepian, merasa tidak aman berdekatan dengan orang lain, pasien biasanya mengatakan hubungan yang tidak berarti dengan orang lain, pasien tidak mampu berkonsentrasi dan pasien dengan isolasi sosial biasanya tidak mampu untuk mengambil keputusan. Seseorang dengan masalah isolasi sosial akan merasa cepat bosan dan lambat menghabiskan waktunya selain itu pasien merasa tidak berguna. Ketika masalah tersebut semakin terus muncul pada pikiran pasien isolasi sosial maka pasien tersebut akan merasa bahwa dirinya tidak yakin dapat melangsungkan hidupnya (Keliat,dkk. 2011). Berdasarkan pengalaman peneliti pada saat melakukan lab klinik di Rumah Sakit Jiwa Menur Surabaya peneliti menemukan bahwa orang dengan masalah keperawatan isolasi sosial mereka cenderung menghindar dan tidak mau berbicara terhadap orang yang baru dikenalnya, ketika ditanya mereka akan menjawab dengan jawaban seadanya dan mereka akan cenderung untuk meninggalkan tempat sebelum pembicaraan itu selesai, saat ada seseorang yang mengajaknya berbicara pasien dengan isolasi sosial tidak ada kontak mata dengan pembicaranya bahkan mereka cenderung untuk melihat ke arah lain seperti keatas, ataupun ke bawah, saat diberikan pertanyaan pasien isolasi sosial akan menjawab seadanya. Pada pasien isolasi sosial dapat dilakukan tindakan keperawatan yaitu dengan memberikan asuhan keperawatan, ada 3 strategi pelaksanaan (SPTK) dalam melakukan tindakan asuhan keperawatan pada pasien isolasi sosial. Saat melakukan asuhan keperawatan pada pasien dengan gangguan jiwa seharusnya dapat diselesaikan dalam waktu \pm 3 minggu tetapi pada pasien isolasi sosial membutuhkan waktu yang lama untuk melakukan pendekatan pada pasien, seperti melakukan tindakan keperawatan SP1 yaitu membina hubungan saling percaya, peneliti dapat menyelesaikan $\mathrm{Sp} 1$ tersebut dalam waktu 1 minggu. Tetapi walaupun Sp1 tersebut dapat dipenuhi pasien dengan isolasi sosial tersebut tidak sepenuhnya mau bicara dengan perawat, mereka mau bicara dengan perawat jika perawat mengajaknya untuk berbicara dan mereka tidak mau untuk memulai pembicaraan. Sehingga hal tersebut dapat menyebabkan kemampuan bersosialisasi pasien isolasi sosial mengalami gangguan. Kemampuan bersosialisasi merupakan kemampuan seseorang dalam melakukan tindakan sosialisasi terhadap orang lain seperti pasien mampu untuk berinteraksi dengan orang lain, ketika bertemu mereka saling menegur, berjabat tangan, dan saling berbicara. Menurut Kelliat (2005) pada pasien dengan isolasi sosial dapat dilakukan dengan terapi modalitas, salah satunya yaitu terapi aktivitas kelompok. Terapi aktivitas kelompok merupakan salah satu terapi modalitas yang dilakukan perawat kepada sekelompok klien yang mempunyai masalah keperawatan yang sama. Ada beberapa macam jenis terapi aktivitas kelompok salah satunya yaitu Terapi Aktivitas Kelompok Sosialisasi (TAKS). Terapi Aktivitas Kelompok (TAK): Sosialisasi (TAKS) adalah upaya memfasilitasi kemampuan sosialisasi sejumlah klien dengan masalah hubungan sosial (Keliat, 2005). Berdasarkan pengalaman peneliti saat melakukan lab klinik di rumah sakit Jiwa Menur Surabaya kegiatan TAK yang dilakukan tidak sepenuhnya diikuti oleh pasien isolasi sosial. Terapi Aktivitas Kelompok tersebut bertujuan untuk meningkatkan hubungan sosial dalam kelompok secara bertahap sehingga pasien mampu memperkenalkan diri dengan orang lain, pasien mampu berkenalan dengan anggota kelompok yang mengikuti terapi aktivitas kelompok.

Menurut data dari Word Health Organization (WHO) masalah gangguan kesehatan jiwa sudah menjadi masalah yang sangat serius. WHO menyatakan tahun 2001 paling tidak satu dari empat orang di dunia mengalami masalah mental. WHO memperkirakan ada sekitar 450 juta orang di dunia yang mengalami gangguan jiwa (Yoseph, 2009). Menurut DepKes RI jumlah penderita gangguan jiwa saat ini mencapai lebih dari 28 juta orang dengan kategori gangguan jiwa ringan $11,06 \%$, dan $0,46 \%$ penderita gangguan jiwa berat. Menurut Riset Kesehatan Dasar (Riskesdas, 2013) pada penduduk usia diatas 15 tahun, dijumpai Prevalensi Orang Dengan Gangguan Jiwa (ODGJ) ringan atau gangguan mental emosional seperti gangguan kecemasan dan depresi sebesar $6 \%$ atau 16 juta orang dan Prevalensi Orang Dengan Gangguan Jiwa 
(ODGJ) berat seperti Psikosis sebesar 1,72/ 1.000 atau estimasi 400. 000 orang. Di Jawa timur menurut Riskesdas (Riset Kesehatan Dasar) tahun 2007, didapatkan data nasional tentang angka kejadian gangguan jiwa berat (skizofrenia) di Jawa Timur sebesar $1,4 \%$ dan Surabaya tercatat sebanyak $0,2 \%$. Sedangkan gangguan mental emosional (seperti kecemasan, depresi, dll) sebesar 35\% dan di Surabaya tercatat 18,8\%. Berdasarkan data Rumah Sakit Jiwa (RSJ) Menur Surabaya, dari tahun ke tahun jumlah pasien rawat inap penderita kesehatan jiwa terus naik. Pada 2011 ada 2.460 pasien. Setahun kemudian jumlahnya bertambah menjadi 2.582 pasien. Nah, tahun ini, hingga semester I (Januari-Juni), sudah ada 1.350 pasien. Sehingga tiap bulan terdapat 328 pasien di Rumah Sakit Jiwa Menur Surabaya. Gangguan jiwa skizofrenia menimbulkan masalah yang negatif pada penderitanya yaitu pada fungsi sosialnya seperti isolasi sosial. Menurut Maramis (2006) dalam jurnal Anjas Surtiningrum (2011) mengatakan klien mengalami isolasi sosial sebesar 72\% kasus Skizofrenia, 64\% mengalami penurunan kemampuan memelihara diri (makan, mandi, dan berpakaian). Dengan demikian dapat disimpulkan bahwa $72 \%$ klien mengalami masalah isolasi sosial sebagai akibat dari kerusakan kognitif dan afektif. Berdasarkan studi pendahuluan yang dilakukan peneliti disalah satu ruangan di Rumah Sakit Jiwa Menur Surabaya yaitu di Ruang Puri Mitra Permata Harapan terdapat 17 pasien yang dirawat di dan 7 diantaranya mengalami gangguan isolasi sosial.

Menurut Damaiyanti (2012) isolasi sosial dipengaruhi oleh 2 faktor yaitu faktor predisposisi dan factor presipitasi. Pada faktor predisposisi meliputi, faktor perkembangan, faktor biologi, dan faktor sosial budaya. Sedangkan pada faktor presipitasi terjadinya isolasi sosial meliputi factor internal maupun eksternal seperti stressor sosial budaya dan stressor biokimia. Penyebab yang terjadi pada pasien isolasi sosial tersebut dapat menyebabkan koping individu inefektif seperti ketidakberdayaan, menyangkal tidak mampu menghadapi kenyataan dan menarik diri dari lingkungan, tidak mampu menerima realitas dengan rasa syukur sehingga hal tersebut dapat menyebabkan harga diri rendah kronik pada pasien. Jika harga diri rendah kronik pada pasien tidak segera ditangani pada pasien, maka pasien tersebut akan mengalami isolasi sosial karena mereka lebih suka untuk menyendiri daripada bergabung dengan teman-temannya karena menurut mereka tidak ada yang bisa membantunya dalam menyelesaikan masalahnya, pasien merasa bosan dan lambat menghabiskan waktu, pasien merasa tidak berguna. Isolasi sosial yang dialami oleh pasien dapat menyebabkan masalah yang lebih serius jika tidak segera diatasi seperti halusinasi. Halusinasi yang dialami oleh pasien dikarenakan pasien lebih suka menyendiri dan tidak mau bersosialisasi kepada orang lain sehingga menimbulkan kenyamanan terhadap kesendiriannya yang dapat mengakibatkan munculnya perasaan-perasaan seperti melihat seseorang ataupun mendengar seseorang berbicara. Ketika pasien sudah memasuki pada fase halusinasi dan tidak segera diatasi, masalah yang serius lagi yang akan dialami oleh pasien yaitu PK atau perilaku kekerasan, sehingga proses penyembuhan pada pasien akan menjadi lama.

Pasien isolasi sosial dapat dilakukan dengan memberikan asuhan keperawatan dan tindakan terapi. Asuhan keperawatan yang dilakukan pada pasien isolasi sosial yaitu membina hubungan saling percaya, membantu pasien mengenal penyebab isolasi sosial, membantu pasien mengenali keuntungan dari membina hubungan dengan orang lain, membantu pasien mengenal kerugian dari tidak membina hubungan, membantu pasien untuk berinteraksi dengan orang lain secara bertahap. Sedangkan pada terapi, ada beberapa macam terapi yang dapat dilakukan pada pasien isolasi sosial salah satunya yaitu terapi aktivitas kelompok. Terapi aktivitas kelompok terdiri dari terapi aktivitas kelompok stimulasi kognitif/ persepsi, terapi aktivitas kelompok stimulasi sensori, terapi aktivitas kelompok orientasi realitas, dan terapi aktivitas kelompok sosialisasi. Pada penelitian ini penulis melakukan terapi aktivitas kelompok sosialisasi. Pada penelitian ini peneliti menggunakan 7 sesi dengan indicator pada sesi 1 pasien isolasi sosial dapat memperkenalkan dirinya dengan baik, sesi 2 pasien isoalsi sosial dapat berkenalan dengan orang lain secara baik, pada sesi 3 pasien isolasi sosial dapat bercakap-cakap dengan orang lain secara baik, sesi ke-4 pada terapi aktivitas kelompok sosialisasi pasien isoalsi sosial dapat bercakap-cakap topic tertentu dengan baik, sesi ke-5 pada terapi aktivitas kelompok sosialisasi pasien isoalsi sosial dapat bercakap-cakap masalah pribadi dengan baik, sesei ke-6 pada terapi aktivitas kelompok sosialisasi pasien isolasi sosial dapat bekerja sama dengan orang lain secra baik, dan pada sesi ke-7 pasien isolasi sosial dapat bersosialisasi dengan baik kepada orang lain. 
METODE

Dalam penelitian ini rancangan yang digunakan adalah quasi eksperiment dengan metode one-group pra-post test design, yaitu mengungkapkan hubungan sebab akibat dengan cara melibatkan satu kelompok subjek, metode penelitian ini ditujukan untuk menguji pengaruh terapi aktivitas kelompok sosialisasi terhadap kemampuan bersosialisasi. Sebagai populasi dalam penelitian adalah semua Pasien skizofrenia yang mengalami Isolasi Sosial Di Ruang Puri Mitra Harapan Rumah Sakit Jiwa Menur Surabaya sebanyak 7 orang, yang diambil menggunakan tehnik total sampling Pasien skizofrenia yang mengalami isolasi sosial Di Ruang Puri Mitra Harapan Rumah Sakit Jiwa Menur Surabaya sebanyak 7 orang. Variabel bebas dalam penelitian ini adalah terapi aktivitas kelompok sosialisasi dan variabel terikat dalam penelitian ini adalah kemampuan bersosialisasi.

\section{HASIL DAN PEMBAHASAN}

1. Karakteristik responden berdasarkan umur

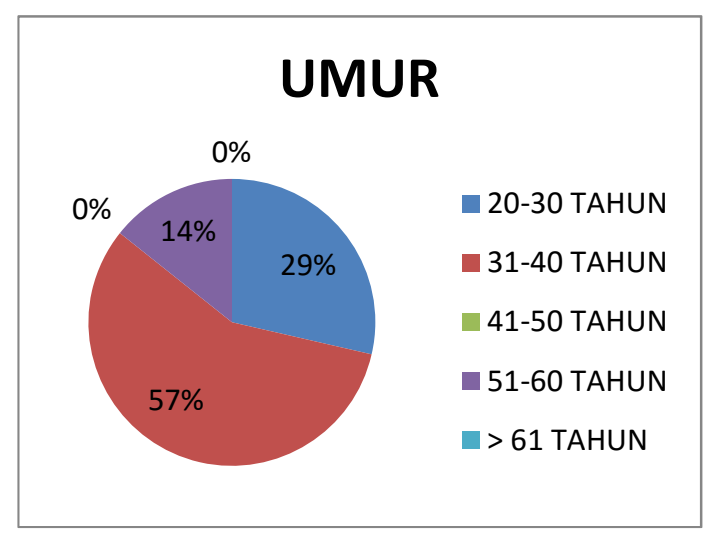

Diagram 1 Diagram pie karaktristik responden isolasi sosial berdasarkan umur di ruang Puri Mitra Permata Harapan Rumah Sakit Jiwa Menur Surabaya, Desember 2015.

Berdasarkan gambar 1 dapat diketahui sebagian besar responden berumur 31-40 tahun yaitu sebanyak $57 \%$.
2. Karakteristik responden berdasarkan pendidikan

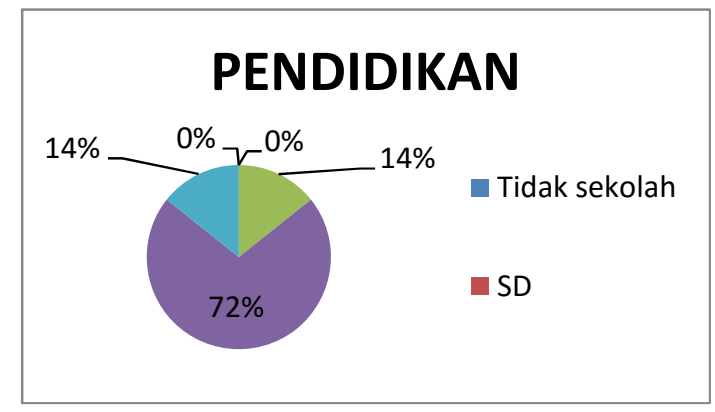

Diagram 2 Diagram pie karaktristik responden isolasi sosial berdasarkan pendidikan di Ruang Puri Mitra Permata Harapan Rumah Sakit Jiwa Menur Surabaya, Desember 2015.

Berdasarkan gambar 2 dapat diketahui sebagian besar responden memiliki tigkat pendidikan SMA yaitu sebanyak $72 \%$.

3. Karakteristik responden berdasarkan status perkawinan

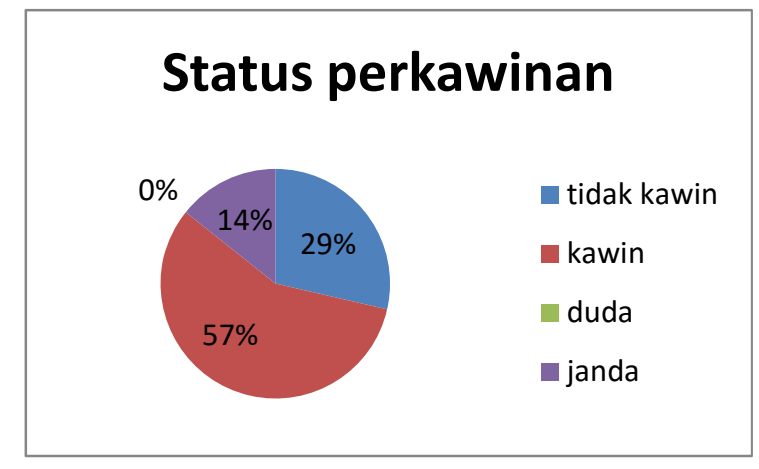

Diagram 3 Diagram pie karaktristik responden isolasi sosial berdasarkan status perkawinan di Ruang Puri Mitra Permata Harapan Rumah Sakit Jiwa Menur Surabaya, Desember 2015.

Berdasarkan gambar 3 dapat diketahui sebagian besar responden memiliki status perkawinan sebanyak $57 \%$. 
4. Karakteristik responden berdasarkan lama dirawat di RSJ

\section{Lama dirawat di RSJ}

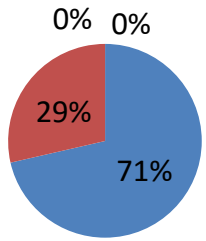

- 0-1 bulan

1-2 bulan

2-3 bulan

n >3 bulan

Diagram 5.4 Diagram pie karaktristik responden isolasi sosial berdasarkan lama dirawat di RSJ di Ruang Puri Mitra Permata Harapan Rumah Sakit Jiwa Menur Surabaya, Desember 2015

Gambar .4 dapat diketahui sebagian besar responden lama dirawat di RSJ terbanyak yaitu 01 bulan $(71 \%)$.

5. Karakteristik responden berdasarkan berapa kali dirawat di RSJ

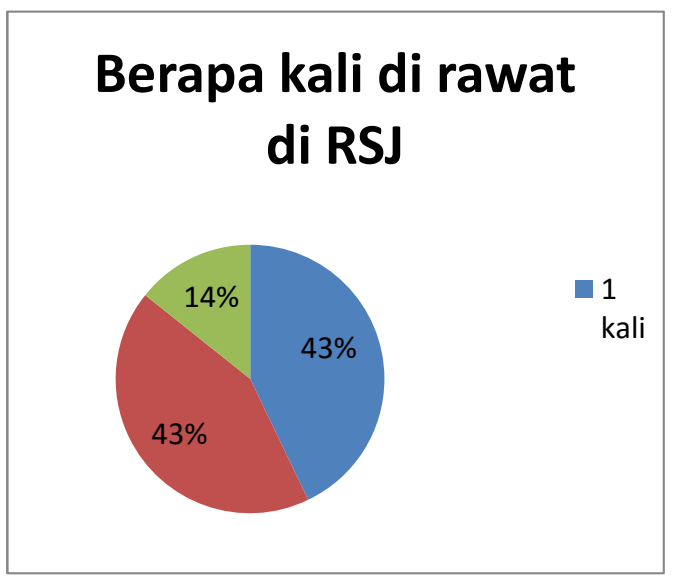

Diagram 5. Diagram pie karaktristik responden isolasi sosial berdasarkan berapa kali dirawat di RSJ di Ruang Puri Mitra Permata Harapan Rumah Sakit Jiwa Menur Surabaya, Desember 2015.

Berdasarkan gambar 5 dapat diketahui sebagian responden pernah di rawat di Rumah Sakit Jiwa sebanyak 2-3 kali (43\%) dan 1 kali $(43 \%)$.
Data Khusus

Karakteristik responden berdasarkan kemampuan bersosialisasi sebelum pelaksanaan Terapi Aktivitas Kelompok : Sosialisasi

\begin{tabular}{rrrr} 
Tabel 1 & \multicolumn{1}{c}{ Distribusi frekuensi resonden } \\
& berdasarkan & kemampuan \\
& bersosialisasi sebelum & pelaksanaan \\
& Terapi Aktivitas & Kelompok \\
& Sosialisasi di Ruang & Puri Mitra \\
& Permata Harapan Rumah Sakit Jiwa \\
& Menur Surabaya, Desember 2015.
\end{tabular}

\begin{tabular}{ccc}
\hline $\begin{array}{c}\text { Kemampuan } \\
\text { bersosialisasi }\end{array}$ & Jumlah & Presentase \\
\hline Mampu & 0 & $0 \%$ \\
Tidak mampu & 7 & $100 \%$ \\
\hline Total & 7 & $100 \%$ \\
\hline
\end{tabular}

Berdasarkan tabel 1 dapat diketahui bahwa seluruh responden tidak mampu bersosialisasi sebelum pelaksanaan Terapi Aktivitas Kelompok Sosialisasi dengan jumlah responden 7 orang sebanyak (100\%).

2. Karakteristik responden berdasarkan kemampuan bersosialisasi sebelum pelaksanaan Terapi Aktivitas Kelompok : Sosialisasi

Tabel 2. Distribusi frekuensi resonden berdasarkan kemampuan bersosialisasi setelah pelaksanaan Terapi Aktivitas Kelompok Sosialisasi di Ruang Puri Mitra Permata Harapan Rumah Sakit Jiwa Menur Surabaya, Desember 2015.

\begin{tabular}{ccc}
\hline $\begin{array}{c}\text { Kemampuan } \\
\text { bersosialisasi }\end{array}$ & Jumlah & Presentase \\
\hline Mampu & 5 & $8 \%$ \\
Tidak mampu & 2 & $2 \%$ \\
\hline Total & 7 & $100 \%$ \\
\hline \multicolumn{2}{c}{ Berdasarkan tabel } & 2 \\
diketahui bahwa dapat \\
tidak mampu bebagian responden \\
betelah
\end{tabular}


pelaksanaan Terapi Aktivitas Kelompok Sosialisasi dengan jumlah responden 2 orang $(2 \%)$ sedangkan responden yang mampu bersosialisasi sebanyak 5 orang $(8 \%)$.

3. Tabulasi Silang Kemampuan bersosialisasi sebelum dengan sesudah pelaksanaan TAK : Sosialisasi

Tabel 3. Tabulasi silang kemampuan bersosialisasi sebelum dan setelah pelaksanaan Terapi Aktivitas Kelompok Sosialisasi di Ruang Puri Mitra Permata Harapan Rumah Sakit Jiwa Menur Surabaya

\begin{tabular}{ccccc}
\hline Pelaksa & Pre & Post & $\%$ \\
Bersosialisasi & & & & \\
\hline Mampu & 0 & $0 \%$ & 5 & $8 \%$ \\
Tidak mampu & 7 & $100 \%$ & 2 & $2 \%$ \\
Total & 7 & $100 \%$ & 7 & $100 \%$ \\
\hline Uji Wilcoxson $\mathrm{P}=0,025$ & & &
\end{tabular}

Berdasarkan tabel 3 diketahui bahwa hasil dari penelitian di Ruang Puri Mitra Permata Harapan Rumah Sakit Jiwa Menur Surabaya seluruh responden tidak mampu bersosialisasi yaitu sebanyak $100 \%$, dan setelah pelaksanaan Terapi Aktivitas kelompok Sosialisasi sebanyak 5 orang (8\%) mampu bersosialisasi sedangkan responden yang tidak mampu bersosialisasi sebanyak 2 orang $(2 \%)$.

Hasil analisis dari uji wilcoxson diketahui bahwa nilai $\mathrm{p}=0,025$ yaitu $\mathrm{p}<\alpha(0,05)$ sehingga dapat dikatakan bahwa ada pengaruh Terapi Aktivitas Kelompok Sosialisasi terhadap kemampuan bersosialisasi pada pasien isolasi sosial diagnosa skizofrenia di Ruang Puri Mitra Permata Harapan Rumah Sakit Jiwa Menur Surabaya.

\section{PEMBAHASAN}

Pada pembahasan akan diuraikan hasil penelitian dari kemampuan bersosialisasi sebelum pelaksanaan Terapi Aktivitas Kelompok Sosialisasi, kemampuan bersosialisasi setelah pelaksanaan Terapi Aktivitas Kelompok Sosialisasi, dan pengaruh Terapi Aktivitas Kelompok Sosialisasi terhadap kemampuan bersosialisasi di Ruang Puri Mitra Permata Harapan Surabaya, Desember 2015.
Kemampuan responden dalam bersosialisasi sebelum pemberian Terapi Aktivitas Kelompok Sosialisasi terhadap pasien isolasi sosial.

Berdasarkan tabel 1 kemampuan pasien bersosialisasi sebelum pelaksanaan TAKS dapat dilihat bahwa seluruh responden tidak mampu bersosialisasi yaitu sebanyak 7 orang (100\%). Berdasarkan informasi yang didapat pelaksanaan TAK sudah dilakukan setiap hari tetapi masih ada pasien yang tidak mampu bersosialisasi dengan lingkungannya. Menurut Kuntjoro (1989) dalam jurnal Jhon (2009) ada beberapa aspek ketidakmampuan bersosialisasi salah satunya yaitu tingkah laku, hal ini berhubungan dengan kebutuhan sosial dalam kehidupan bermasyarakat seperti bergaul. Jika kemamapuan bergaulnya baik maka kemampuan bersosialisasi seseorang juga ikut baik. Berdasarkan hasil penelitian bila dikaitkan dengan teori maka terdapat keselarasan antara fakta dengan teori yang ada. Menurut peneliti hal ini disebabkan karena seseorang yang sulit untuk bergaul dengan orang lain mereka cenderung tidak memiliki teman sehingga mereka merasa lebih nyaman terhadap dirinya sendiri daripada bergaul dengan orang lain. hal ini dapat menyebabkan responden tidak memiliki kemampuan dalam bersosialisasi, sehingga didapatkan hasil seluruh responden tidak mampu dalam bersosialisasi sebelum dilakukan TAKS.

Berdasarkan data yang diperoleh dari diagram 2 dapat diketahui bahwa paling banyak responden dengan lama dirawat di RSJ memiliki frekuensi yang sama yaitu 1 dan 2-3 kali (43\%). Menurut Keliat (2010) menyebutkan penyebab dari perilaku isolasi sosial adalah harga diri rendah yaitu perasaan negative terhadap diri sendiri, hilang kepercayaan diri, rasa gagal mencapai keinginan yang ditandai dengan perasaan malu terhadap diri sendiri, rasa bersalah terhadap diri sendiri serta gangguan hubungan sosial. Berdasarkan hasil penelitian jika dikaitkan dengan teori maka terdapat keselarasan anatara fakta dan teori. Menurut peneliti hal tersebut dapat terjadi karena adaya pengalaman yang dialami oleh responden, dimana pengalaman tersebut dapat berpengaruh terhadap persepsi responden karena stigma negative dari lingkungannya seperti seringnya keluar masuk Rumah Sakit Jiwa. Hal ini membuat responden malas berinteraksi dengan orang lain dan menjauh dari orang lain sehingga didapatkan hasil penelitian yang menunjukkan sebelum dilakukannya taks seluruh responden tidak mampu bersosialisasi. 
Faktor lain yang membuat seluruh responden tidak mampu bersosialisasi salah satunya yaitu gangguan jiwa yang dialami sebelumnya seperti halusinasi dan resiko perilaku kekerasan. Berdasarkan gambaran umum yang peneliti dapatkan dari 7 orang responden memiliki riwayat gangguan persepsi sensori halusiansi sebanyak 4 orang (57\%) dan responden yang memiliki riwayat resiko perilaku kekerasan sebanyak 3 orang (43\%). Menurut teori Damaiyanti (2012) penyebab terjadinya gangguan persepsi sensori halusinasi adalah isolasi sosial, sedangkan menurut Iyus (2011) seseorang dengan Harga Diri Rendah mereka mengalami perasaan cemas, merasa tidak mampu, tidak memiliki percaya diri, hal-hal tersebut bila tidak disalurkan dengan cara yang tepat maka pasien tersebut dapat menyebabkan koping individu inefektif salah satunya resiko perilaku kekerasan. Berdasarkan hasil penelitian bila dikaitkan dengan teori terdapat kesenjangan antara fakta dengan teori. Menurut peneliti hal itu dapat terjadi karena kemungkinan gangguan persepsi sensori halusinasi responden masih muncul, sehingga reponden mungkin masih merasakan kenyamanan terhadap halusinasi tersebut akibatnya responden tersebut masih suka menyendiri, tidak dapat berinteraksi dengan baik, sedangkan pada responden perilaku kekerasan mungkin sebelumnya responden tersebut memiliki riwayat isolasi sosial yang tidak tampak atau mungkin juga responden tersebut sejak awal mengalami resiko perilaku kekerasan karena halusinasi, sehingga didapatkan hasil seluruh responden tidak mampu bersosialisasi.

Kemampuan pasien bersosialisasi setelah pemberian Terapi Aktivitas Kelompok Sosialisasi terhadap pasien isolasi sosial.

Berdasarkan tabel 2 kemampuan pasien bersosialisasi setelah dilakukan tindakan terapi aktivitas kelompok sosialisasi didapatkan data bahwa sebagian responden mampu untuk bersosialisasi yaitu sebanyak 5 orang $(8 \%)$ dan responden tidak mampu bersosialisasi sebanyak 2 orang (2\%). Kemampuan bersosialisasi responden tersebut dipengaruhi oleh salah satu terapi yaitu terapi aktivitas kelompok sosialisasi, terapi tersebut dilakukan selama 45 menit dalam waktu 8 hari. Pengaruh terhadap terapi aktivitas kelompok sosialisasi tersebut didukung oleh teori dari Budi Anna Kelliat dimana yang mengemukakan bahwa terapi aktivitas kelompok sosialisasi adalah upaya memfasilitasi kemampuan sosialisasi sejumlah klien dengan masalah hubungan sosial. Berdasarkan hasil penelitian yang dikitkan dengan teori terdapat kesamaan antara fakta dengan teori. Menurut peneliti hal ini dapat dikatakan bahwa terapi aktivitas kelompok sosialisasi tersebut dapat membantu seseorang dalam bersosialisasi terhadap orang lain sehingga mereka akan cenderung mudah bergaul dan bekerja sama dengan orang lain tanpa memiliki rasa ketidakpercayaan terhadap dirinya. Sehigga terdapat peningkatan kemampuan bersosialisasi terhadp responden.

Faktor yang mendasari responden mampu untuk bersosialisasi setelah dilakukan terapi aktivitas kelompok sosialisasi salah satunya yaitu faktor pendidikan. Menurut diagram 2 diagram pie berdasarkan karakteristik pendidikan terhadap pasien isolasi sosial didapatkan data, sebagian besar responden berpendidikan SMA sebanyak 72\%. Menurut Prof Dr.John Dewey yang mengartikan bahwa pendidikan merupakan suatu proses pengalaman. Dimana pengalaman tersebut dapat mempengaruhi tingkat sosialisasi seseorang. Berdasarkan hasil penelitian bila dikaitkan dengan teori maka terdapat keselarasan antara fakta dan teori. Menurut peneliti hal tersebut dapat terjadi karena semakin tinggi tingkat pendidikan seseorang maka semakin banyak pengalaman yang didapatkan, jadi saat dilakukan terapi aktivitas kelompok sosialisasi mereka telah mampu melakukannya karena sebelumnya mereka telah memiliki pengalaman, sehingga terjadi peningkatan kemampuan bersosialisasi terhadap responden.

Kemampuan bersosialisasi seseorang dapat dipengaruhi juga terhadap lamanya dirawat di RSJ. Berdasarkan diagram 4 lama responden dirawat dirsj sebagian besar responden tersbut dirawat antara 0-1 bulan sebanyak 71\%, Menurut Noviandi (2008) yang menyatakan semakin lama pasien dirawat maka semakin banyak pasien tersebut mendapat terapi pengobatan dan perawatan. Berdasarkan hasil penelitian bila dikaitkan dengan teori maka terdapat keselarasan antara fakta dengan teori yang ada. Menurut peneliti hal tersebut dapat terjadi karena responden sering mendaatkan pengobatan dan perawatan seperti terapi aktivitas kelompok sosialisasi, dimana setiap sesi dalam terapi tersebut memiliki pengaruh yang baik terhadap kemampuan seseorang dalam bersosialisasi. Sehingga terjadi peningkatan kemampuan bersosialisasi terhadap responden.

Berdasarkan gambar 1 mengenai karakteristik umur pada responden dapat diketahui bahwa sebagian responden berumur 3140 tahun (57\%), dimana dalam tumbuh kembang 
pada usia tersebut termasuk dalam usia dewasa muda. Menurut Sunaryo (2004) pada fase dewasa memiliki tugas perkembangannya yaitu belajar untuk saling ketergantungan dan tanggung jawab terhadap orang lain. dimana tanggung jawab tersebut dapat mempengaruhi seseorang dalam bergaul dengan orang lain. Berdasarkan hasil penelitian bila dikaitkan dengan teori terdapat keselarasan antara fakta dengan teori yang ada. Menurut peneliti, ketika seseorang memiliki tanggung jawab terhadap orang lain mereka cenderung akan mudah menerima informasi dari orang lain baik itu informasi bersifat positif maupun negative, jadi pada saat pelaksanaan terapi aktivitas kelompok sosialisasi responden mudah untuk melewati persesinya karena mereka mudah untuk menerima informasi dari orang lain sehingga setelah pelaksanaan TAKS terjadi perubahan terhadap diri mereka yaitu mampu untuk bergaul dan berinteraksi terhadap orang lain. sehingga terdapat peningkatan kemampuan bersosialisasi terhadap responden.

\section{Pengaruh Terapi Aktivitas Kelompok Sosialisasi terhadap kemampuan bersosialisasi pasien isolasi sosial.}

Berdasarkan tabel 3 mengenai tabulasi silang kemampuan bersosialisasi sebelum dan setelah pelaksanaan Terapi Aktivitas Kelompok Sosialisasi, terlihat ada pengaruh yang signifikan terhadap responden tersebut. Seperti pada saat sebelum dilakukan tindakan terapi aktivitas kelompok sosialisasi dari 7 responden yang peneliti temui seluruh responden tidak mampu bersosialisasi dengan baik, sedangkan pada saat setelah dilakukan tindakan terapi aktivitas kelompok sosialisasi dari 7 responden, 5 responden mampu untuk bersosialisasi dengan baik sedangkan 2 responden tidak mampu bersosialisasi dengan baik. Dalam terapi Aktivitas Kelompok Sosialisasi terdapat 7 sesi dimana didalam ketujuh sesi tersebut terdapat komponen persesi diantaranya yaitu pada sesi pertama responden diajarkan untuk memperkenalkan diri, hal ini sesuai dengan tujuan TAKS yang dikemukakan oleh Budi Anna Keliat (2005) bahwa tujuan dari terapi aktivitas kelompok sosialisasi sesi 1 yaitu klien mampu untuk memperkenalkan diri. Berdasarkan hasil penelitian bila dikaitkan dengan teori terdapat keselarasan antara fakta dengan teori yang ada. Menurut peneliti hal tersebut dapat terjadi karena saat dilakukan TAKS pada sesi 1 responden mampu untuk menyebutkan nama lengkap, nama panggilan, hobi, dan alamat rumahnya. Pada sesi kedua responden diajarkan untuk berkenalan.
Menurut Budi Anna Keliat (2005) tujuan pelaksanaan TAKS sesi 2 yaitu klien mampu berkenalan dengan anggota kelompok. Berdasarkan hasil penelitian bila dikaitkan dengan teori terdapat keselarasan antara fakta dengan teori yang ada. Menurut peneliti hal tersebut dapat terjadi karena saat dilakukan TAKS pada sesi 2 responden dapat menyebutkan nama lengkap, nama panggilan, hobi, dan alamat teman kelompoknya. Sesi ketiga responden diajarkan untuk bercakap-cakap. Menurut Budi Anna Keliat (2005) tujuan dilaksanakan terapi aktivitas kelompok sosialisasi pada sesi 3 yaitu klien mampu bercakap-cakap dengan anggota kelompok. Berdasarkan hasil penelitian bila dikaitkan dengan teori terdapat keselarasan antara fakta dengan teori yang ada. Menurut peneliti hal tersebut dapat terjadi karena saat dilakukan TAKS ada sesi 3 responden mampu untuk bertaya dan menjawab pertanyaan dari teman kelompoknya. Pada sesi keempat responden diajarkan untuk bercakap-cakap topic tertentu. Menurut Budi Anna Keliat (2005) tujuan dilakukan TAKS sesi 4 yaitu klien mampu menyampaikan dan membicarakan topic percakapan. Berdasarkan hasil penelitian bila dikaitkan dengan teori terdapat keselarasan antara fakta dengan teori yang ada. Menurut peneliti hal tersebut dapat terjadi karena saat dilakukan TAKS pada sesi 4 responden mampu untuk memilih, menyampaikan, dan memberi pendapat terhadap topic yang disampaikan. Pada sesi kelima responden diajarkan untuk bercakapcakap masalah pribadi. Menurut Budi Anna Keliat (2005) tujuan dilaksanakan TAKS pada sesi 5 yaitu klien mampu menyampaikan dan membicarakan masalah pribadi kepada orang lain. Berdasarkan hasil penelitian bila dikaitkan dengan teori terdapat keselarasan antara fakta dengan teori yang ada. Menurut peneliti hal tersebut dapat terjadi karena saat dilakukan TAKS ada sesi 5 responden mampu untukmenyampaikan, memilih, dan memberi pendapat terhadap orang lain. Pada sesi keenam responden diajarkan untuk bekerja sama. Menurut Budi Anna Keliat (2005) tujuan dilaksanakan terapi aktivitas kelompok sosialisasi pada sesi 6 yaitu klien mampu bekerja sama dalam permainan sosialisasi kelompok. Berdasarkan hasil penelitian bila dikaitkan dengan teori terdapat keselarasan antara fakta dengan teori yang ada. Menurut peneliti hal tersebut dapat terjadi karena saat dilakukan TAKS ada sesi 6 responden mampu untuk bertanya, menjawab, dan meminta bantuan terhadap anggota kelompoknya. Pada sesi ketujuh responden 
diajarkan untuk bersosialisasi. Menurut Budi Anna Keliat (2005) tujuan dilaksanakannya TAKS pada sesi ke-7 yaitu klien mampu menyampaikan pendapat tentang manfaat kegiatan TAKS yang telah dilakukan. Berdasarkan hasil penelitian bila dikaitkan dengan teori terdapat keselarasan antara fakta dengan teori yang ada. Menurut peneliti hal tersebut dapat terjadi karena saat dilakukan TAKS pada sesi 7 responden mampu untuk menyebutkan manfaat dilakukannya terapi aktivitas kelompok sosialisasi. Jadi dalam ketujuh komponen tersebut dapat diketahui bahwa terapi aktivitas kelompok sosialisasi memiliki pengaruh yang baik terhadap kemampuan bersosialisasi terhadap orang lain, karena dengan melakukan terapi aktivitas kelompok sosialisasi seseorang dapat berinteraksi dengan baik terhadap orang lain sehingga responden tersebut memiliki rasa percaya diri dan eningkatan harga diri ketika bergaul dengan orang lain.

\section{SIMPULAN DAN SARAN}

Berdasarkan hasil penelitian yang dilakukan dengan jumlah responden 7 orang mengenai pengaruh Terapi Aktivitas Kelompok Sosialisasi terhadap kemampuan bersosialisasi pada pasien isolasi sosial diagnose skizofrenia di Ruang Puri Mitra Permata Harapan Rumah Sakit Jiwa Menur Surabayadapat diambil kesimpulan 1) Kemampuan pasien isolasi sosial diagnose skizofrenia dalam bersosialisasi sebelum pemberian Terapi Aktivitas Kelompok Sosialisasi didapatkan bahwa semua responden tidak mampu bersosialisasi dengan baik yaitu sebanyak 7 orang. 2) Kemampuan pasien isolasi sosial diagnose skizofrenia dalam bersosialisasi setelah pemberian Terapi Aktivitas Kelompok Sosialisasi didapatkan bahwa sebagian besar responden mampu untuk bersosialisasi dengan baik sebanyak 5 orang. 3) Ada pengaruh Terapi Aktivitas Kelompok Sosialisasi terhadap kemampuan bersosialisasi pada pasien isolasi sosial diagnose skizofrenia. Saran yang dapat diberikan adalah 1) dosen dapat menerapkan terapi aktivitas kelompok sosialisasi kepada mahasiswa saat turun dinas di ruangan sehingga mahasiswa dapat menerapkannya dengan baik dan benar, 2) diharapkan untuk terus melakukan terapi aktivitas kelompok sosialisasi, khusunya pada paien isolasi sosial, agar kemampuan bersosialisasi pada pasien isolasi sosial semakin baik.

\section{DAFTAR PUSTAKA}

Ardi Al-Maqqasari. 2014. Pengertian rasa percaya diri (Jurnal hasil riset). Jakarta

: $\quad$ www.ejurnal.com/2014/03/pengertian-rasapercaya-diri.html. Diunduh pada tanggal 23 Nov 2015 pukul 14.00

Damaiyanti Mukhripah, Dkk. 2012. Asuhan Keperawatan Jiwa. Bandung : Refika aditama

Dyanrch. 2015. Definisi permainan menurut para ahli . Jakarta

dyanrch.weebly.com/designcourse/definisi-permainan-menurutpara-ahli. Diunduh pada tanggal 23 Nov 2015 pukul 18.28

Efendi Surya, dkk. 2012. Pengaruh Pemberian Terapi AKtivitas Kelompok Sosialisasi Terhadap Perubahan Perilaku Klien Isolasi Sosial. Padang : jurnal.fkep.unand.ac.id/index.php/ners/ article/download/73/68. Diunduh tanggal 25 Oktober 2015 Pukul 15.08

Hawari, Dadang. 2006. Pendekatan Holistik Pada Gangguan Jiwa Skizofrenia. Jakarta: Balai Penerbit FKUI

Ibrahim Sani Ayub. 2011. Skizofrenia Splitting Personality. Tangerang: Jelajah Nusa

Jhon Edision Purba. 2009. Pengaruh Intervensi Rehabilitasi Terhadap Ketidakmampuan Bersosialisasi Pada Penderita Skizofrenia. Medan : Repository.Usu.Ac.Id/Bitstream/12345 6789/6915/1/09E01834.Pdf. Diunduh Pada Tanggal 23 Nov 2015 Pukul 13.00

Keliat Anna Budi, Dkk. 2007. Keperawatan Kesehatan Jiwa Komunitas: CMHN. Jakarta: EGC

Akemat. 2004. Terapi Aktivitas Kelompok. Jakarta : EGC

Nursalam. 2003. Konsep dan Penerapan Metodologi Penelitian Ilmu Keperawatan. Jakarta : Salemba Medika

Purwaningsih Wahyu, Ina Karlina. 2010. Asuhan Keperawatan Jiwa Terapi Modalitas Dan Standard Operating Procedure (SOP). Yogyakarta : Nuha Medika

PT. Jpg Multimedia. 2014. Pendertita Gangguan Jiwa Terus Naik. Jakarta : Www.Jpnn.Com/News/PenderitaGangguan-Jiwa-Terus-Naik. Diunduh Tanggal 19 November 2015 Pukul 15.19

Setiadi. 2007. Konsep dan Penulisan Riset Keperawatan. Jakarta : Graha Permai 
Sunaryo.2004. Psikologi Untuk

Keperawatan. Jakarta : EGC

Surtiningrum Anjas. 2010. Pengaruh Terapi

Suportif Terhadap Kemampuan

Bersosialisasi Pada Klien Isolasi Sosial.

Semarang

$\underline{\text { Lib.Ui.Ac.Id/File?File=Digital/...T\%20 }}$

Anjas\%20Surtiningrum.Pdf.Diunduh

tanggal 10 November 2015 Pukul 12.07

Yoseph Iyus. 2011. Keperawatan Jiwa. Bandung

: Refika Aditama 